\title{
Sumbangan Teknologi Hijau Dalam Ketamadunan Islam
}

\author{
Norizan Hassan ${ }^{\text {* }}$, Hussin Salamon ${ }^{a}$, Hasimah Abdul Rahman ${ }^{b}$ \\ ${ }^{a}$ Fakulti Tamadun Islam, Universiti Teknologi Malaysia, 81310 UTM Johor Bahru, Johor, Malaysia \\ ${ }^{b}$ Centre of Electrical Energy Systems (CEES), Universiti Teknologi Malaysia, UTM Johor Bahru, Johor, Malaysia
}

*Corresponding author: norizan32@live.utm.my

\begin{abstract}
Green technology refers to the development and application of products, equipment and systems to protect the environment and the natural environment and minimize the negative impact of human activities. Positive elements in green technologies should be focused on the elements that benefit the environment. But otherwise have occurred. Human activities have resulted in a variety of greedy negative changes to the earth such as climate change, global warming and pollution. This is because man has lost Islamic values in themselves. Therefore, how green technology can contribute to Islamic civilization and portrays Islam entirely discussed in this article. The objective of this study is to analyze how green technology can contribute to Islamic civilization and can filled with features that prescribed in Islam. This study will use qualitative methods in which sources of information from journal articles, books and online database. Findings have shown that the green technology can contribute in Islamic civilization and show that green technology has been filled with the value of Islam such as environmental protection, energy saving and environmental sustainability awareness. These areas have also contributed in terms of environmental protection and restore human civilization increasingly barren due to the greed in this world. Studies of green technology can also provide a space for Muslims to explore this area in accordance with the Quran and the Sunnah and thus can contribute to environmental sustainability, which result in benefits to the present generation and the next.
\end{abstract}

Keyword: Green technology; sustainable; islamic civilization

\begin{abstract}
Abstrak
Teknologi hijau merujuk kepada pembangunan dan aplikasi produk, peralatan serta sistem untuk memelihara alam sekitar dan alam semulajadi serta meminimumkan kesan negatif terhadap aktiviti manusia. Elemen positif dalam teknologi hijau harus difokuskan kepada unsur-unsur yang memberikan manfaat kepada alam sekitar. Akan tetapi sebaliknya telah berlaku. Aktiviti manusia yang rakus telah menyebabkan berlakunya pelbagai perubahan negatif kepada bumi seperti perubahan iklim, pemanasan global dan pencemaran. Ini adalah disebabkan manusia telah hilang nilai-nilai Islam dalam diri. Sehubungan dengan itu, bagaimana teknologi hijau dapat memberi sumbangan dalam ketamadunan Islam dan menggambarkan Islam itu secara menyeluruh dibincangkan dalam kajian ini. Objektif kajian ini ialah menganalisis bagaimana bidang ilmu teknologi hijau dapat menyumbang dalam ketamadunan Islam dan memberi gambaran satu bidang ilmu yang penuh dengan ciri-ciri yang disyariatkan dalam Islam. Kajian ini menggunakan kaedah kualitatif dimana sumber maklumat daripada jurnal artikel, buku dan data dalam talian. Dapatan kajian telah menunjukkan bahawa bidang teknologi hijau mampu menyumbang kepada ketamadunan Islam dan mengambarkan bahawa bidang ini telah dilengkapi dengan ciri-ciri yang disyariatkan dalam Islam seperti wujud unsur-unsur penjagaan alam sekitar, penjimatan tenaga dan kesedaran melestarikan alam sekitar. Bidang ini juga telah memberi sumbangan dari segi pemeliharaan alam sekitar serta mengembalikan ketamadunan manusia yang semakin tandus akibat kerakusan dengan harta dunia. Ilmu teknologi hijau juga dapat memberi ruang kepada Muslim untuk meneroka bidang ini dengan berilmukan al-Quran dan as-Sunnah dan seterusnya dapat menyumbang kepada kelestarian alam sekitar yang menghasilkan manfaat kepada generasi masa kini dan masa depan.
\end{abstract}

Kata Kunci: Teknologi hijau; kelestarian alam; tamadun islam

(C) 2016 Penerbit UTM Press. All rights reserved

\subsection{PENGENALAN}

Manusia diciptakan sebagai khalifah Allah dan manusia sangat ditegaskan untuk menjaga kelestarian alam sekitar. Malangnya, ketika ini khalifah Allah ini telah melanggar amanah-amanah Allah dengan rakusnya untuk mengejar keduniaan semata-mata. Manusia kini juga dengan sewenang-wenangnya memproses bahan-bahan industri tanpa memikirkan impak yang bakal menimpa alam sekitar. Kesan daripada aktiviti perindustrian yang berleluasa menyebabkan karbon dioksida dilepaskan dengan begitu banyak dan seterusnya menyebabkan penipisan ozon dan pemanasan global. Bukan setakat itu sahaja, kesan juga dapat dilihat untuk jangka masa panjang seperti mana ketika ini dapat dilihat iklim dunia telah berubah dan luar daripada kebiasaan, pencairan bongkah ais di kutub utara yang semakin cepat daripada kebiasaan dan perubahan empat musim.

Pentingnya kesedaran dalam pembangunan lestari pada masa kini kerana tanpa kesedaran itu, alam diterokai tanpa memikirkan akibatnya. Pembangunan lestari banyak dibincangkan oleh pengkaji-pengkaji dan mereka mempunyai pandangan yang tertentu berkenaan komponen yang perlu ada untuk mewujudkan pembangunan lestari. Menurut Burnett (2007) dan Abdul Samad, Shaharudin, Abdul Hadi, dan Ahmad Fariz (2011), komponen pembangunan lestari meliputi tiga perkara iaitu pembangunan ekonomi, sosial dan persekitaran. Ketiga-tiga komponen ini melahirkan pembangunan lestari secara menyeluruh. Ini dapat digambarkan dalam Rajah 1. 


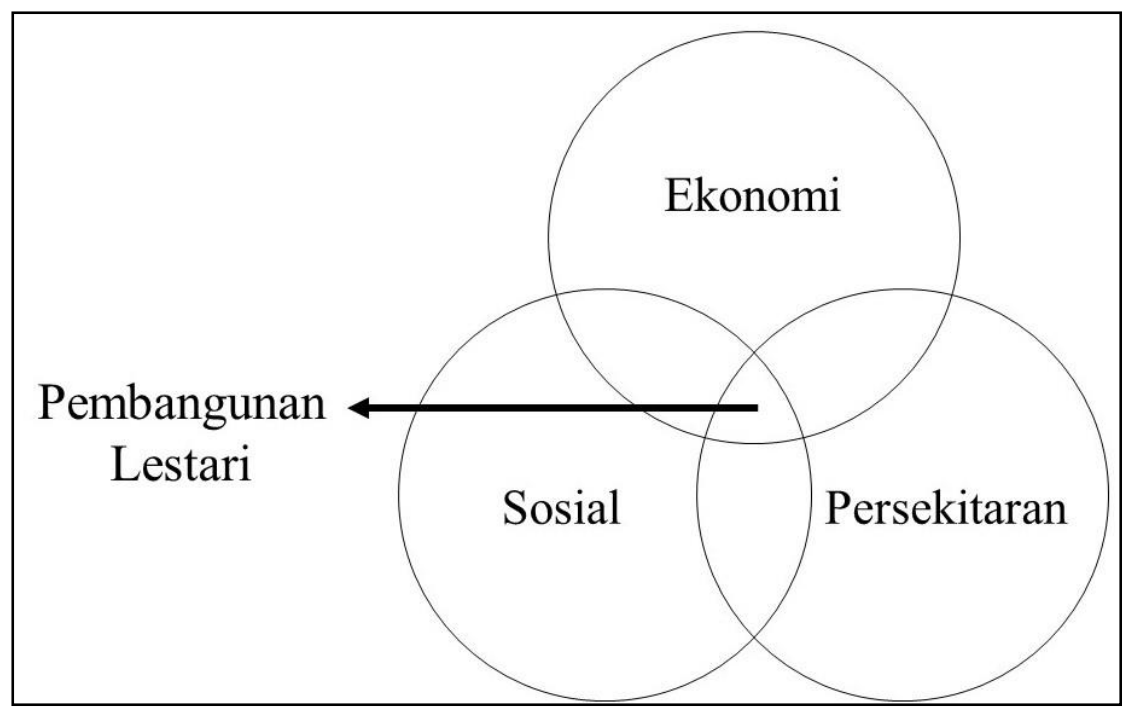

Rajah 1 Komponen pembangunan lestari (Abdul Samad et al., 2011; Burnett, 2007)

Ketandusan sumber alam juga menyebabkan persekitaran terjejas. Ini bermakna komponen persekitaran yang merupakan komponen penting dalam pembangunan lestari ini turut terjejas. Dunia kini telah memperkenalkan usaha untuk mengurangkan pencemaran alam dan menampung ketandusan sumber alam. Teknologi hijau menjadi salah satu usaha yang terbabit. Teknologi hijau dilihat mampu membantu manusia untuk mencapai pembangunan lestari. Akan tetapi, adakah teknologi hijau ini juga mampu menyumbang sesuatu kepada ketamadunan Islam dan memberikan gambaran Islam secara menyeluruh? Kajian ini membincangkan berkenaan sumbangan teknologi hijau dalam ketamadunan Islam dan nilai-nilai Islam yang dapat digambarkan melalui teknologi hijau.

Kajian ini membahagikan perbincangan kepada dua bahagian iaitu perbincangan berkenaan harmonisasi antara tamadun Islam, sains teknologi dan juga kelestarian alam sekitar dan sumbangan teknologi hijau dalam ketamadunan Islam. Kajian ini menggunakan kaedah analisis kandungan dengan menganalisis maklumat daripada artikel jurnal, buku dan data dalam talian.

\subsection{METODOLOGI KAJIAN}

Analisis kandungan merupakan salah satu daripada kaedah dalam penyelidikan kualitatif. Menurut Ahmad Sunawari (2015), analisis kandungan melibatkan beberapa garis panduan untuk mencapai penganalisaan yang berkesan. Antaranya ialah:

i. Meneliti isi kandungan dokumen untuk tujuan pencarian isi-isi penting.

ii. Menilai isi kandungan dengan terperinci sama ada ia berdasarkan sumber yang benar dan relevan dengan kajian yang dijalankan

iii. Membuat perbandingan dengan dokumen berlainan untuk mendapatkan idea, dapatan, teknik dan teori baru.

iv. Membuat kesimpulan pada akhir penganalisaan dalam bentuk yang kritis dan tidak berat sebelah terhadap maklumat yang diperoleh.

Penulis mendapati artikel berkenaan tajuk ini masih lagi kurang diterbitkan dan disebabkan itu sokongan daripada bahan lain juga penting. Data dalam talian iaitu sumber internet juga digunakan dengan maklumat dalam laman sesawang rasmi kerajaan seperti laman sesawang Kementerian Tenaga, Teknologi Hijau dan Air (KeTTHA) untuk maklumat formal dan laman sesawang rasmi Skim Pembiayaan Teknologi Hijau (Green Technology Financing Scheme) untuk dapatan data berbentuk angka.

Penulis kemudiannya menganalisis maklumat yang diperoleh dan persembahkan dalam bentuk rajah untuk memberi gambaran yang lebih jelas berkenaan keseluruhan hasil kajian.

\subsection{PERKAITAN ANTARA KELESTARIAN ALAM SEKITAR, SAINS TEKNOLOGI DAN TAMADUN ISLAM}

\section{Kelestarian Alam Sekitar Menurut Perspektif Islam}

Islam telah menegaskan bahawa setiap manusia adalah khalifah dan bertanggungjawab menjalankan amanah menjaga alam ini. Begitu juga dengan kebersihan alam sekitar yang menjadi amanah kepada khalifah di muka bumi ini. Dalam al-Quran telah dijelaskan mengenai larangan merosakkan harta benda dan alam. Larangan ini telah dijelaskan dalam Surah al-Baqarah ayat 11 dan 12 yang bermaksud:

\footnotetext{
'Dan apabila dikatakan kepada mereka: "Janganlah kamu membuat bencana dan kerosakan di muka bumi", mereka menjawab: "Sesungguhnya Kami orang-orang yang hanya membuat kebaikan". Ketahuilah! Bahawa sesungguhnya mereka itulah orangorang yang sebenar-benarnya membuat bencana dan kerosakan, tetapi mereka tidak menyedarinya'.
}

Allah S.W.T telah menyatakan bahawa manusia yang melakukan kerosakan bakal mengundang kemurkaannya. Firman Allah dalam sebahagian surah al-Ma'idah ayat 64 yang bermaksud: 


\begin{abstract}
'........dan mereka pula terus-menerus melakukan kerosakan di muka bumi, sedang Allah tidak suka kepada orang-orang yang
\end{abstract} melakukan kerosakan.'

Sesungguhnya Allah Maha Mengetahui semua perkara termasuk manusia itu sendiri. Sikap tidak tanggungjawab manusia itu telah ditegur oleh Allah sejak dahulu lagi melalui al-Quran. Segala kerosakan yang berlaku di muka bumi ini adalah disebabkan oleh tangantangan manusia itu sendiri. Sikap manusia yang tidak mengendahkan alam sekitar memberi kesan kepada ketamadunan Islam itu sendiri. Aspek spiritual antara aspek penting untuk meningkatkan hubungan manusia dengan alam (Hazura \& Sharifah Norhaidah, 2007). Manusia lebih terarah dalam melakarkan kelestarian alam sekitar dengan panduan Islam yang telah lama dicoretkan dalam al-Quran. Allah S.W.T telah menegur golongan yang meminggirkan hubungan baik dengan alam. Bahkan, perbincangan berkenaan pencemaran alam ini dilebarkan lagi dengan pendapat-pendapat daripada ulama' (Abdul Basir, 2005).

\title{
Kelestarian Alam, Sains Teknologi dan Tamadun Islam
}

Jamalinezhad, Talakesh, dan Soltani (2012) menegaskan bahawa dengan aspek dan prinsip dalam Al-Quran dan hadis dapat menyumbang kepada kualiti hidup. Manusia dan alam merupakan dua komponen utama dalam ekosistem kehidupan manusia. Kedua-duanya telah diwujudkan bersama, saling bergantungan dan saling berkaitan. Jika salah satu mengalami zaman kepupusan, keseluruhan ekosistem akan musnah (Ruzian \& Norizan, 2014). Kini, kerosakan alam yang berlaku mungkin sukar dipulihkan. Sains teknologi menjadi satu cabang ilmu yang berpotensi membantu melestarikan alam semulajadi. Kewujudan teknologi hijau yang sinonim dengan memartabatkan kelestarian alam sekitar menjadi salah satu daripada bidang ilmu sains teknologi yang mampu membawa kebaikan kepada tamadun Islam. Sejarah juga telah melakarkan bahawa ketamadunan Islam juga pernah gemilang dengan bidang ilmu sains dan teknologi.

Pada tahun 750M sehingga 1100M merupakan zaman kegemilangan sains dan teknologi Muslim. Sejarah juga telah menunjukkan bahawa Islam mempunyai zaman kegemilangannya. Masyarakat Islam itu sendiri telah membina satu tradisi sains dan teknologi yang mendorong pertumbuhan dan kewujudan teknologi moden di Eropah (Alias, 2013). Selama 800 tahun di bawah pemerintahan Islam, Sepanyol telah menjadi sebuah negara yang bertamadun dan berpengetahuan tinggi.

Ketamadunan Islam telah memberi sumbangan dari pelbagai ilmu dan tersebar di seluruh tamadun dunia. Bidang ilmu yang disumbangkan merangkumi bidang sains dan teknologi, perancangan bandar, sistem perparitan dan seni bina. Ini dapat dilihat selepas abad ke 9, senibina Tamadun India banyak dipengaruhi oleh Islam (Mohd Koharuddin, 2002). Islam telah berkembang dan Islam juga telah mendorong masyarakatnya menghasilkan penemuan-penemuan baru.

Dalam bidang sains perubatan contohnya, Ibnu Sina merupakan ahli dan bidang ini dan karya beliau telah menjadi bahan rujukan utama selama beberapa abad. Ketokohan beliau telah diperakui oleh sarjana Barat dan penemuan beliau adalah sesuatu yang luar biasa. Sumbangan Ibnu Sina sangat besar dan menjadi bukti bahawa Islam membawa kepada penemuan ilmu-ilmu baru yang memberi manfaat seluruh umat manusia (Mohd Koharuddin, 2002).

Tamadun Islam telah membangun pesat dengan bidang ilmu sains dan teknologi yang hebat. Kehadiran ilmuwan yang bijak dalam tamadun ini menguatkan lagi asas pengukuhan sesebuah tamadun. Bukan hanya tertakluk kepada sesebuah tamadun sahaja, bidang ilmu yang diterokai tersebar luas dan dipraktikkan di tamadun-tamadun yang lain.

Kewujudan bidang ilmu teknologi hijau yang merupakan cabang ilmu sains dan teknologi dan juga mempunyai prinsip-prinsip memelihara dan memuliharakan alam sekitar. Teknologi hijau mampu menjadi satu bidang ilmu yang membawa kepada kegemilangan ketamadunan manusia kerana kegemilangan ketamadunan itu terletak pada ilmu pengetahuan manusia.

\subsection{SUMBANGAN BIDANG ILMU TEKNOLOGI HIJAU DALAM ISLAM DAN KETAMADUNAN}

\section{Konsep Teknologi Hijau}

Teknologi hijau juga dikenali sebagai Environmental Technology dan Clean Technology. Istilah yang digunapakai merujuk kepada maksud yang sama dan juga fungsi yang sama. Menurut Kamarudin, Mohd Fazli, Md Nor Hayati, Ismi Rajiani, dan Norhana (2011), teknologi hijau ialah satu inisiatif menggabungkan pelbagai kaedah dan bahan-bahan tertentu, daripada teknik penjanaan elektrik kepada produk mesra alam iaitu yang bebas daripada sumber-sumber pencemaran seperti pembebasan karbon dioksida. Selain itu, didefinisikan juga sebagai gabungan sains alam sekitar dan teknologi dijadikan komponen utama untuk diaplikasikan kepada penghasilan produk dan sistem yang bertujuan untuk mengurangkan kesan negatif kepada alam sekitar akibat daripada aktiviti manusia (Farahwahida, Arieff Salleh, Salwa, Siti Hajar, \& Teh Ubaidah, 2013).

Teknologi hijau juga adalah satu bentuk inovasi tenaga (Puvanasvaran, Miza Farhana, Zaid Ahmaed Al-Hayali, \& Mukhiffun, 2012). Aplikasi teknologi hijau terhasil daripada tenaga hijau yang diterokai manusia. Tanpa teknologi hijau, tenaga hijau sukar untuk direalisasikan dalam kehidupan manusia kerana tiada peralatan, produk atau sistem. Teknologi hijau dikatakan sebagai inovasi tenaga kerana daripada tenaga hijau ia dibentuk menjadi sebuah aplikasi peralatan, produk dan sistem yang memudahkan manusia menggunakannya tanpa mengabaikan kelestarian alam sekitar.

Teknologi hijau dikategorikan sebagai alat yang selamat untuk digunakan. Fungsi teknologi hijau dapat dilihat sebagai menyediakan persekitaran sihat, menjimatkan tenaga dan sumber asli serta menggalakkan sumber-sumber yang boleh diperbaharui. Teknologi hijau ini terbukti lebih cekap kerana dapat menjana tenaga dalam pelbagai keadaan dengan selamat dan mesra pengguna. Ini dapat dibuktikan melalui amalan di negara-negara maju yang telah berjaya membangunkan industri ini sejak sekian lama dan menjadi alternatif sumber tenaga baru kepada masyarakat dunia.

Menurut Kamarudin et al. (2011), teknologi hijau ialah satu inisiatif menggabungkan pelbagai kaedah dan bahan-bahan tertentu, daripada teknik penjanaan elektrik kepada produk mesra alam iaitu yang bebas daripada sumber-sumber pencemaran seperti pembebasan karbon dioksida. Konsep teknologi hijau saling berkaitan dengan tenaga hijau. Aktiviti yang melibatkan tenaga hijau dilihat sebagai medium untuk membantu manusia memelihara kelestarian alam sekitar yang direalisasikan melalui industri teknologi hijau. 
Teknologi hijau merupakan satu cabang ilmu pengetahuan sains dan teknologi. Bidang sains dan teknologi merupakan bidang yang banyak disumbangkan oleh tamadun-tamadun dunia. Jika dilihat dari sudut ketamadunan ini, tamadun Asia telah memberikan banyak sumbangan dari segi bidang ilmu kepada dunia. Kecemerlangan tamadun Asia telah terbukti melalui penemuan bidang-bidang seperti sains dan teknologi, astronomi, sains perubatan, fizik, biologi dan zoologi (Mohd Koharuddin, 2002). Tamadun Asia ini meliputi tamadun ArabIslam, Mesir, India, China dan Melayu. Ini juga jelas menunjukkan bahawa bidang ilmu telah dipelopori oleh umat Islam dan telah membangunkan tamadun dunia. Sehubungan dengan itu, ilmu teknologi hijau juga dilihat sebagai bidang ilmu yang dilengkapi oleh ciriciri syariat Islam yang membawa kepada pembentukan nilai sesebuah tamadun.

Menurut Dasar Teknologi Hijau Kebangsaan (KeTTHA, 2009), teknologi hijau merujuk pembangunan dan aplikasi produk, peralatan serta sistem untuk memelihara alam sekitar dan alam semulajadi dan meminimumkan atau mengurangkan kesan negatif daripada aktiviti manusia. Teknologi Hijau merujuk produk, peralatan, atau sistem yang memenuhi kriteria-kriteria berikut:

i. Ia meminimumkan degrasi kualiti persekitaran, mempunyai pembebasan Gas Rumah Hijau (GHG) yang rendah atau sifar, selamat untuk digunakan dan menyediakan persekitaran sihat dan lebih baik untuk semua hidupan

ii. Menjimatkan tenaga dan sumber asli

iii. Menggalakkan sumber-sumber yang boleh diperbaharui

Teknologi hijau membawa harapan untuk membaiki ketamadunan manusia dengan penerapakan ciri-ciri Islam. Teknologi hijau telah menjadi satu bidang ilmu yang memberi sumbangan kepada pemeliharaan dan pemuliharaan alam sekitar secara praktikal. Dengan wujud pelbagai peralatan berteknologi hijau, masyarakat telah didedahkan dengan ciri-ciri teknologi hijau yang memberi impak positif kepada semesta ini. Akan tetapi, bagaimana teknologi hijau ini dapat menggambarkan ciri-ciri keIslaman yang mampu menarik lebih ramai manusia untuk meminati Islam? Perkara ini akan dibincangkan dengan lebih terperinci.

\section{Teknologi Hijau dan Islam}

Teknologi hijau merupakan cabang ilmu yang berguna yang berpotensi untuk memelihara alam sekitar yang bukan sahaja dapat memberi manfaat kepada masyarakat kini, bahkan ia dapat memberi manfaat berpanjangan kepada generasi akan datang. Bidang ilmu teknologi hijau merupakan sebuah ilmu yang harus dipelajari untuk dijadikan sebagai panduan hidup dalam merangka keharmonian dan kelestarian alam. Jujun S. Suriasumantri menegaskan bahawa ilmu tenaga hijau dan teknologi perlu dipelajari supaya manusia dapat meneroka rahsia alam dan mencipta peralatan untuk mengawal gejala alam yang kurang sihat bersesuaian dengan hukum alam. Beliau menggariskan lima pendekatan pengintegrasian Islam dan teknologi seperti berikut (Nahadi, Sarimaya, \& Rosdianti, 2011):

i. Islam adalah agama yang mendorong, merangsang dan menyumbang ilham kepada penemuan ilmu persekitaran dan teknologi. Sebagai contoh, tokoh Abdus Salam seorang pengkaji Islam telah membuktikan bagaimana harmonisasi antara Islam sebagai sumber keyakinan dan inspirasi dengan ilmu pengetahuan alam sebagai hasil fikir dan eksperimen umat manusia. Teori ini dikenali sebagai unified field teory yang merupakan satu teori yang menyatakan semua unsur di dunia ini adalah wujud daripada satu kekuatan yang tunggal. Ia melibatkan semua unsur seperti unsur elektromagnet magnet dan unsur elektrik;

ii. Islam memberi sumbangan berharga dalam pengembangan ilmu persekitaran dan teknologi. Ini dilihat daripada perspektif sejarah Islam yang begitu banyak memberi sumbangan kepada pengembangan ilmu tentang alam dan teknologi. Sebagai contohnya zaman Al-Khindi yang turut menyumbang pada zaman Abdus Salam;

iii. Ada hubungan yang sangat erat antara falsafah, Islam dan teknologi sebagai landasan aksiologi, epistemologi dan ontologi dalam sains dan teknologi. Islam bukan sahaja fokus kepada landasan aksiologi iaitu bagaimana manusia menggunakan ilmu, tetapi asal usul ilmu dan juga realiti kehidupan kini. Keseluruhan kajian ini menunjukkan terdapat hubungan yang erat antara falsafah, Islam dan teknologi;

iv. Ilmu persekitaran dan teknologi merupakan sumber nilai inspirasi bagi manusia dari segi kemajuan, kesejahteraan dan keselamatan di dunia mahupun di akhirat. Misalnya, ilmu berkenaan alam sekitar mampu memberi sumbangan kepada manusia untuk memajukan alam sekitar dengan sebaiknya. Ini bukan sahaja membantu dari segi pembangunan negara, bahkan ia membantu golongan tidak berkemampuan dan yang pasti ia juga menyumbang kepada saham akhirat kerana membantu orang lain; dan

v. Islam, persekitaran dan teknologi saling berkaitan untuk kelestarian ekosistem kehidupan. Dengan adanya undang-undang syariah dan ketetapan dalam Islam, kelestarian ekosistem kehidupan dapat dikekalkan dan teknologi berkembang seiring dengan usaha untuk mememelihara alam sekitar seperti berkembangnya teknologi hijau.

Rajah 2 menunjukkan bagaimana teknologi hijau itu boleh menggambarkan Islam dan bagaimana perkara di sebalik teknologi hijau dapat dilaksanakan tanpa mencemari bidang ilmu ini. 


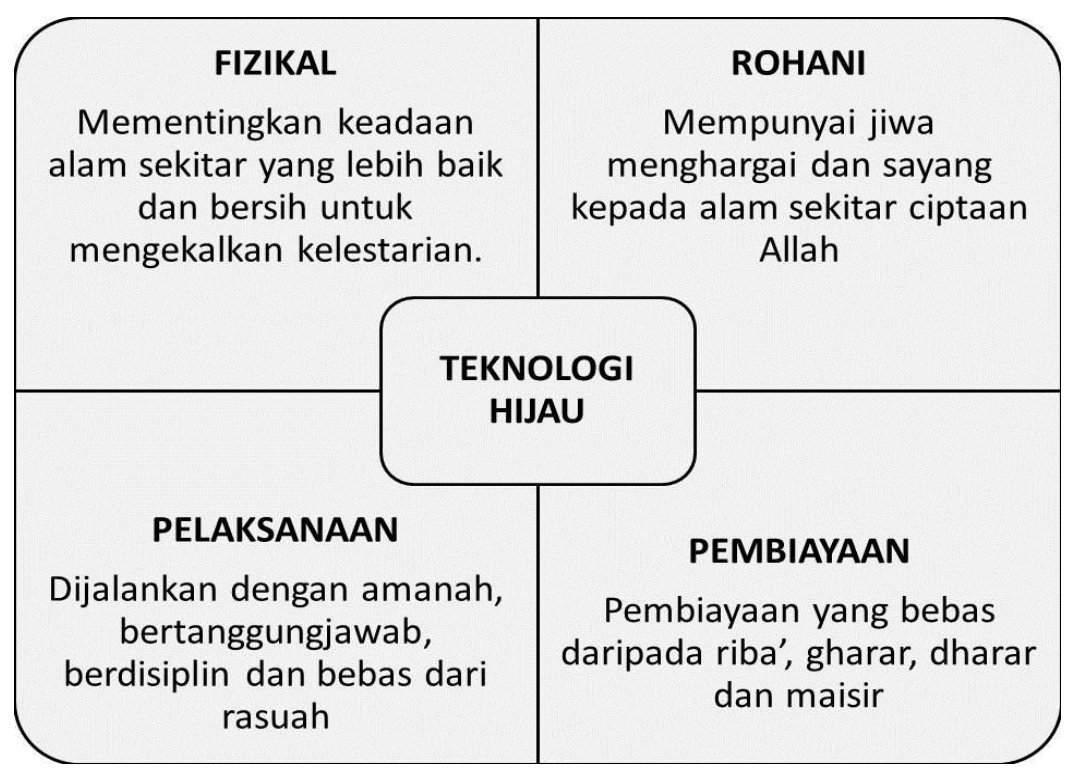

Rajah 2 Gambaran ciri-ciri keIslaman dalam teknologi hijau

Bagaimana sebuah bidang ilmu yang lahir daripada bidang tenaga hijau dapat memberi gambaran nilai-nilai Islam adalah melalui beberapa sudut iaitu:

i. $\quad$ Aspek fizikal atau kebendaan (Nahadi et al., 2011)

Teknologi hijau itu sendiri telah melahirkan nilai-nilai Islam daripada pelaksanaannya melalui mementingkan keadaan alam sekitar yang lebih baik, bersih serta mampu untuk mengurangkan kesan pelepasan karbon dioksida yang berlebihan.

ii. $\quad$ Aspek kerohanian (Hazura \& Sharifah Norhaidah, 2007)

Aspek kerohanian penting dalam jiwa manusia untuk lebih menghargai hubungan dengan alam. Nilai ini yang mengajar manusia erti sebuah alam kerana manusia itu sendiri sangat bergantung kepada alam sekitar dan begitu juga sebaliknya. Perasaaan ini menjadikan manusia itu lebih bertimbang rasa, lebih menyayangi alam dan tidak mementingkan diri sendiri terutamanya dalam perkara yang melibatkan alam.

iii. Pelaksanaan dan pentadbiran (Mohamad Akram, 2013)

Aspek ini merupakan aspek disebalik pelaksanaan teknologi hijau itu sendiri. Aspek ini perlu diawasi dan perlu dipantau bagi mewujudkan sebuah rangka kerja yang berkualiti dan tidak melanggar mana-mana etika ketika melaksanakannya. Sebuah tadbir urus yang mempunyai nilai dan peraturan Islam perlu dilaksanakan dengan amanah, bertanggungjawab, berdisiplin dan bebas dari perkara yang diharamkan seperti rasuah. Perkara-perkara yang haram ini sebenarnya menjadi punca untuk menjadikan bidang ilmu itu tercemar dan seterusnya menjadikan nilai-nilai Islam itu hilang.

iv. Pembiayaan (Ruzian \& Norizan, 2014)

Jika dilihat dari aspek pembiayaan, teknologi hijau merupakan sebuah cabang ilmu di mana jika ingin dilaksanakan ia memerlukan perbelanjaan yang besar. Ketika ini, institusi kewangan menjadi tunjang utama dalam projek-projek teknologi hijau. Sebuah pembiayaan seharusnya bebas daripada perkara-perkara yang diharamkan oleh Islam seperti riba' dan gharar. Unsur sebegini menjadikan manusia itu sendiri wujud sifat tamak dalam berurusan. Pihak bank mengenakan riba' yang sangat tinggi menyebabkan hilang semua ciri-ciri Islam yang sepatutnya wujud dalam pembiayaan kerana ia sangat berkait rapat dengan bidang ilmu Islam iaitu fiqh muamalat. Menurut prinsip kewangan dan perbankan Islam, terdapat beberapa prinsip asas yang harus dipatuhi kerana tanpa prinsip ini, pengurusan kewangan dan perbankan Islam itu tidak dapat dijalankan dengan baik. Antara prinsip asas tersebut ialah:

a. Kebebasan untuk berkontrak

Untuk memahami prinsip kebebasan berkontrak dalam Islam, perlu difahami bahawa para fuqaha' berpendapat bahawa kesan undang-undang sesuatu akad bukan ditentukan oleh pihak yang berkontrak itu sendiri, tetapi ia ditentukan oleh syarak. Ini bermakna ia perlu mematuhi segala peraturan syarak seperti menghindari riba', gharar dan maysir. Ada sesetengah pengkaji fiqh muamalat beranggapan bahawa syariat Islam tidak mengiktiraf doktrin kebebasan berkontrak seperti yang terdapat dalam perundangan Barat. Realitinya, dalam muamalat Islam, peraturan umum ialah setiap kontrak mesti bebas dari sebarang elemen riba' dan gharar. Oleh itu, bolah dianggap bahawa doktrin kebebasan berkontrak dalam Islam pada asasnya beroperasi antara dua batasan utama iaitu melaksanakan kewajipan kontrak dan perjanjian dan mengelakkan elemen terlarang oleh syarak (Atikullah, 2007).

b. Patuh syariah

Skim pembiayaan Islam yang akan dijalankan wajib untuk menghindari daripada alaman-amalan tidak beretika seperti riba', gharar dan maysir. Kontrak yang mengandungi riba', gharar, maysir sekalipun dipersetujui oleh pihak yang terlibat dalam kontrak, ia tetap tidak dibenarkan kerana prinsip Islam telah dilanggar. Larangan riba' telah dijelaskan dalam Surah AlBaqarah ayat 275 yang bermaksud:

'Orang-orang yang memakan (mengambil) riba itu tidak dapat berdiri betul melainkan seperti berdirinya orang yang dirasuk Syaitan Dengan terhuyung-hayang kerana sentuhan (Syaitan) itu. yang demikian ialah disebabkan mereka mengatakan: 
"Bahawa Sesungguhnya berniaga itu sama sahaja seperti riba". Padahal Allah telah menghalalkan berjual-beli (berniaga) dan mengharamkan riba. Oleh itu sesiapa yang telah sampai kepadanya peringatan (larangan) dari Tuhannya lalu ia berhenti (dari mengambil riba), maka apa yang telah diambilnya dahulu (sebelum pengharaman itu) adalah menjadi haknya, dan perkaranya terserahlah kepada Allah. dan sesiapa yang mengulangi lagi (perbuatan mengambil riba itu) maka itulah ahli neraka, mereka kekal di dalamnya'.

Perbincangan ini jelas menunjukkan bahawa teknologi hijau mempunyai ciri-ciri Islam dan berupaya menyumbang kepada penerapan nilai-nilai Islam itu dalam masyarakat dan negara. Teknologi hijau juga berpotensi menjadi cabang ilmu yang mempunyai nilai Islam untuk menyumbang dalam ketamadunan Islam. Teknologi hijau berupaya menyumbang kepada kegemilangan ketamadunan Islam dengan pelaksanaannya yang telus dan patuh syariah.

Teknologi Hijau dan Ketamadunan

Menurut Syed Naquib Al-Attas (1972), tamadun Islam ialah keadaan kehidupan insan bermasyarakat yang telah mencapai tahap kehalusan tatasusila kebudayaan yang luhur bagi seluruh masyarakatnya. A.S. Homby dan E.C. Pamwell dalam The Progressive English Dictionary menjelaskan tamadun ialah peningkatan pencapaian hidup manusia daripada mundur kepada maju dalam kepelbagaian ilmu seperti ilmu sains, teknologi, politik dan sebagainya.

Jika dilihat dari sudut penjagaan alam sekitar, manusia kini seolah-olah telah mundur kerana mengabaikan ketamadunan mereka sendiri dengan mengabaikan alam ini. Manusia yang bertamadun adalah manusia yang sentiasa memajukan diri sendiri tanpa perlu mengabaikan aspek lain. Kebanyakan kerosakan yang berlaku di muka bumi ini adalah daripada kerakusan tangan-tangan manusia sendiri. Bagaimana ini boleh menggambarkan manusia itu hidup dalam bertamadun sedangkan mereka sendiri tidak mencerminkan nilai-nilai ketamadunan itu?

Teknologi hijau memainkan peranan sebagai satu bidang ilmu yang bukan sahaja boleh menjaga kelestarian alam, akan tetapi dapat menggambarkan Islam secara menyeluruh. Teknologi hijau juga berpotensi dalam memberi sumbangan kepada pemantapan nilai dan ciri tamadun Islam.

Penulis berpendapat bidang ilmu teknologi hijau ini mempunyai perkaitan dengan tamadun Islam dan boleh membentuk sebuah ketamadunan. Ini kerana melalui bidang ilmu, akan lahir manusia yang luhur budi pekertinya dan bertamadun. Ini juga boleh memberi sumbangan kepada kemajuan negara. Bahkan, bukan bidang ilmu ini sahaja yang mempunyai nilai-nilai Islam, semua ilmu di dunia ini mempunyai nilai Islam jika manusia itu sendiri dapat melihat dari sudut yang berbeza.

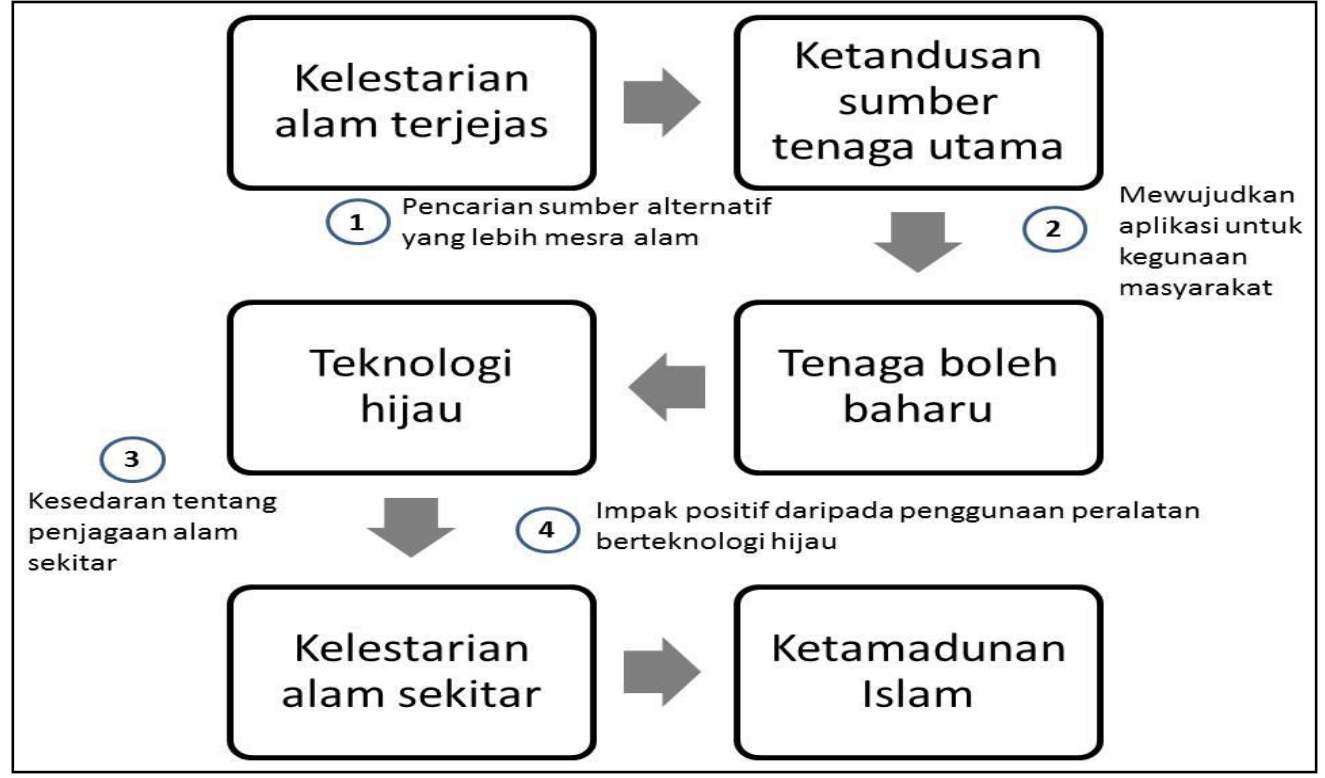

Rajah 3 Carta alir hubungan kelestarian alam, teknologi hijau dan ketamadunan (Sumber: Penulis)

Rajah 3 menunjukkan satu carta alir yang membawa kepada pemantapan nilai dalam ketamadunan Islam. Seperti yang telah dijelaskan sebelum ini, Islam itu sendiri tidak membenarkan manusia untuk menyalahgunakan alam sekitar kepada arah yang bertentangan dengan syariah. Terdapat beberapa ayat-ayat al-Quran yang melarang manusia daripada merosakkan harta benda di muka bumi ini. Ini juga adalah kerana manusia dan alam adalah saling bergantungan.

Kewujudan ilmu teknologi hijau yang diterokai manusia bermula dengan berlakunya pencemaran alam sekitar. Pencemaran alam sekitar berlaku akibat tangan-tangan manusia yang tidak bertanggungjawab memproses bahan-bahan yang mempunyai pelepasan karbon dioksida yang sangat tinggi. Pemprosesan bahan-bahan industri juga melibatkan tenaga yang tidak boleh diperbaharui seperti minyak, arang batu dan gas. Akibat penerokaan dan penggunaan tenaga tersebut secara meluas tanpa memikirkan kesan jangka panjang, sumber tenaga tersebut dilihat semakin berkurangan. 
Dari permasalahan ini telah wujud bidang ilmu tenaga hijau di mana tenaga yang diperoleh adalah tenaga yang boleh diperbaharui seperti tenaga solar, air, angin dan geoterma. Penemuan fungsi tenaga hijau ini memberi sedikit kelegaan bagi masyarakat dunia yang semakin tandus dengan hasil bumi yang menjadi bahan kelangsungan hidup.

Untuk mengaplikasikan tenaga hijau ini, diinovasikan dengan wujudnya bidang ilmu yang bersangkutan dengannya iaitu teknologi hijau. Teknologi hijau ini menjadi satu landasan daripada tenaga hijau kepada aplikasi harian manusia. Melalui aplikasi teknologi hijau ini, manusia mula menyedari berkenaan alam yang semakin sakit dan memerlukan pemuliharaan semula. Impak daripada mengaplikasikan teknologi hijau menjadikan manusia kembali kepada sifat ketamadunan mereka yang sekian lama telah menghilangkan nilai tersebut dalam diri mereka. Ini yang dikatakan teknologi hijau memberi pengaruh kepada manusia dan juga kepada tamadun manusia itu sendiri. Bidang ilmu yang menjadi tunjang kepada pemantapan sesebuah tamadun manusia. Seterusnya, ini akan menyumbang kepada kegemilangan ketamadunan Islam.

\section{Teknologi Hijau dan Ekonomi Negara}

Teknologi hijau yang wujud bukan sahaja membantu meningkatkan kegemilangan ketamadunan Islam, bahkan teknologi hijau mampu meningkatkan ekonomi sesebuah negara. Jika dilihat dari aspek sistem perbankan negara, teknologi hijau membantu meningkatkan jumlah bank-bank yang terlibat dalam projek teknologi hijau. Peningkatan projek setiap tahun menunjukkan ekonomi positif.

Di Malaysia, terdapat 475 projek yang berdaftar di bawah Green Technology Financing Scheme atau Skim Pembiayaan Teknologi Hijau. Jumlah projek ini meningkat dari tahun lepas yang mencatatkan jumlah projek hanya 378 projek (www.gtfs.my). Jumlah projek yang meningkat saban tahun menunjukkan bahawa teknologi hijau berupaya membantu dalam peningkatan ekonomi negara. Peningkatan projek juga menyumbang kepada peningkatan sektor kewangan sebagai medium pembiayaan.

Dalam konteks Islam, pembiayaan mestilah patuh syariah dan bersifat membantu manusia. Untuk konteks teknologi hijau ini, pembiayaan Islam sangat penting berikutan kos projek yang sangat tinggi lebih-lebih lagi jika melibatkan sektor bangunan (Bagoes, 2015; Tam, Hao, \& Zeng, 2012; Tobias \& Vavaroutsos, 2012). Sistem kewangan negara menjadi satu tunjang untuk ekonomi terus berkembang. Bagi sektor teknologi hijau yang masih 'hijau' di negara kita, sokongan daripada sektor kewangan amat penting. Tanpa pembiayaan yang bersesuaian, teknologi hijau tidak mampu menyumbang kepada ekonomi negara. Tanpa pembiayaan yang patuh syariah juga, teknologi hijau tidak mampu untuk terus mempamerkan nilai-nilai Islam dalam pelaksanaannya. Untuk mengekalkan nilai-nilai Islam dalam sistem pembiayaan khusus bagi sektor teknologi hijau, sebuah rangka skim pembiayaan Islam perlu dilakukan seperti rajah 3.

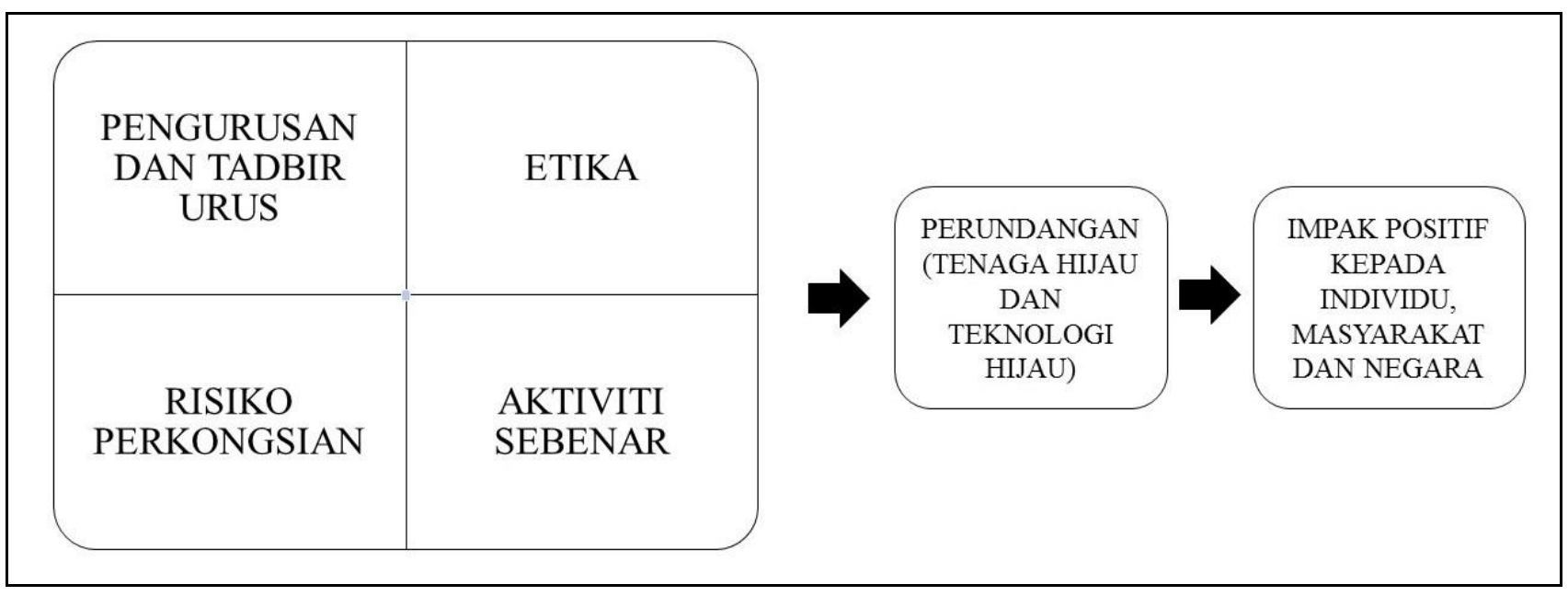

Rajah 4 Rangka skim pembiayaan Islam bagi sektor teknologi hijau (Ruzian \& Norizan, 2014)

Rajah 4 menunjukkan skim pembiayaan Islam bagi sektor teknologi hijau. Jika dilihat daripada rangka ini, terdapat beberapa aspek telah dimasukkan dalam rangka ini bagi memaparkan nilai-nilai Islam. Aspek-aspek tersebut ialah:

i. $\quad$ Pengurusan dan tadbir urus

Tadbir urus merupakan perkara terpenting dalam pelaksanaan skim pembiayaan ini. Pengurusan tadbir ini mestilah mempunyai ketelusan yang tinggi dan patuh syariah bagi memupuk dan mengekalkan nilai-nilai Islam. Ini juga penting untuk memastikan rangka kerja ini dapat dilaksanakan dengan sempurna dan patuh syariah.

ii. Etika

Etika dalam pengurusan perlu diambilkira bagi memastikan sesuatu urusan berjalan lancar. Etika Islam perlu dipupuk pada setiap kakitangan supaya tugasan yang dihasilkan dapat mencapai kualiti yang tinggi. Etika Islam seperti menghindari riba', penipuan, gharar dan maysir perlu ditekankan dalam skim ini supaya dapat dilaksanakan dengan mematuhi semua perkara yang dilarang oleh Islam.

iii. Risiko perkongsian

Untuk kontrak pembiayaan yang dipilih, perlu dinyatakan ciri-ciri kontrak dan ciri-ciri risiko secara jelas dan nyata. Kadar keuntungan juga perlu dibincangkan sebelum dilaksanakan kontrak berkenaan. Sebagai contoh, jika kontrak Mudharabah, pihak bank yang berpegang kepada skim pembiayaan Islam perlu menjelaskan setiap ciri-ciri kontrak ini kepada pelanggan dalam semua perkara meliputi risiko, kadar keuntungan dan juga kerugian. 


\section{iv. Aktiviti sebenar}

Skim pembiayaan Islam ini perlu dilaksanakan selaras dengan suasana ekonomi negara yang sebenar. Dalam aktiviti sebenar ini, perlu dihindari masalah hutang berlebihan melibatkan sektor kewangan dan juga negara secara keseluruhannya.

v. Perundangan

Keempat-empat aspek diatas mestilah dihasilkan selaras dengan perundangan berkaitan dengan tenaga hijau dan teknologi hijau seperti Akta Tenaga Boleh Diperbaharui dan Akta Pihak Berkuasa Pembangunan Tenaga Lestari 2011. Walaupun akta ini tidak secara langsung berkaitan dengan teknologi hijau, perlu diketahui bahawa teknologi hijau sangat berkait rapat dengan tenaga hijau. Tenaga hijau diperkenalkan terlebih dahulu dan kemudiaannya wujud teknologi hijau yang lebih mempraktikkan tenaga hijau dalam bentuk produk.

Aspek-aspek dalam rangka kerja ini diyakini dapat memberi impak positif kepada individu, masyarakat dan juga negara. Nilai-nilai Islam dapat disebarkan kepada semua golongan seperti sifat memelihara alam sekitar dengan menggunakan produk hijau, kontrak pembiayaan patuh syariah dan ekonomi negara yang positif. Perbincangan ini jelas menunjukkan bahawa teknologi hijau menjadi satu bidang berpotensi untuk memajukan ekonomi sesebuah negara.

\subsection{CADANGAN DAN KESIMPULAN}

Manusia membina ilmu pengetahuan untuk memajukan ketamadunan. Ayat ini telah jelas menunjukkan bahawa teknologi hijau merupakan satu bidang ilmu yang boleh membawa kepada kemajuan ketamadunan. Islam menitikberatkan nilai-nilai Islam dan sesebuah bidang ilmu yang telah diterokai. Ilmu itu adalah anugerah daripada Allah S.W.T. Ilmu itu seharusnya tidak dicemari oleh unsur-unsur tidak patuh syariah semasa mempraktikkannya. Teknologi hijau pada asasnya mempunyai nilai-nilai Islam seperti menghargai alam sekitar, penjimatan tenaga, sifat bertoleransi kepada hidupan lain dan juga menjaga kelestarian alam. Nilai-nilai Islam ini sebenarnya membentuk akhlak manusia itu. Manusia yang berakhlak dapat menyumbang kepada ketamadunan sesebuah negara. Dengan budi yang luhur, berakhlak mulia dan ilmu pengetahuan yang mantap, ia sudah cukup untuk melahirkan sebuah tamadun Islam yang kukuh. Cadangan untuk kajian masa depan juga boleh difokuskan kepada bagaimana cara untuk menyerapkan elemen Islam dalam setiap sektor teknologi hijau. Elemen Islam dalam sektor ini sangat penting kerana ia juga melambangkan sesebuah negara yang mengamalkan ajaran Islam. Perkara ini perlulah dibincangkan dengan lebih terperinci dan mungkin boleh diwujudkan satu dasar berkenaan perkara ini.

Daripada perbincangan artikel ini, beberapa perkara dapat dirumuskan, iaitu:

i. Pemeliharaan alam sekitar merupakan komponen penting dalam pembangunan lestari

ii. Hubungan antara kelestarian alam, sains teknologi dan tamadun Islam dapat dilihat melalui zaman kegemilangan Islam menerusi bidang sains dan teknologi yang seterusnya membawa kepada kelestarian alam. Akan tetapi, untuk konteks masa kini di mana alam telah musnah kerana perbuatan manusia, sains teknologi sebagai bidang ilmu yang boleh menjadi alat untuk kembalikan kegemilangan tamadun Islam. Kerosakan alam boleh diatasi dengan wujudnya ilmu teknologi hijau.

iii. Konsep teknologi hijau jelas menunjukkan objektif utama yang berkait rapat dengan menjaga kelestarian alam sekitar.

iv. Konsep teknologi hijau itu sendiri telah menunjukkan persamaan dengan prinsip-prinsip yang telah digariskan dalam Islam berkenaan penjagaan alam sekitar.

v. Teknologi hijau mampu untuk melestarikan semula alam sekitar dan kemudiannya membawa kepada peningkatan martabat ketamadunan Islam kerana prinsip-prinsip Islam itu sendiri telah wujud dalam bidang ilmu teknologi hijau.

vi. Teknologi hijau juga menyumbang kepada peningkatan ekonomi negara dengan wujud lebih banyak projek-projek baru. Secara tidak langsung, teknologi hijau membantu meningkatkan sektor kewangan negara yang menjadi salah satu tunjang kejayaan dalam sesebuah projek dan negara. Seterusnya wujud skim pembiayaan Islam khusus bagi teknologi hijau yang lebih efisien dan mematuhi syariah secara menyeluruh.

Perkara di atas telah jelas menunjukkan bahawa teknologi hijau telah menjadi satu bidang ilmu yang berupaya meningkatkan ketamadunan Islam dan mencerminkan nilai-nilai Islam itu secara tidak langsung. Ini terbukti dengan nilai menjaga kelestarian alam sekitar dalam teknologi hijau selaras dengan suruhan Allah untuk menjaga keharmonian alam sekitar. Keharmonian alam sekitar dapat dijaga dengan rapi dengan gabungan agama Islam dan bidang ilmu teknologi hijau yang secara tidak langsung melahirkan ketamadunan Islam yang gemilang.

\section{Rujukan}

Abdul Basir, M. (2005). Undang-undang dan pengurusan alam sekitar menurut Islam. Malaysian Journal of Environmental Management, 6, 107-124.

Abdul Samad, H., Shaharudin, I., Abdul Hadi, H. S., \& Ahmad Fariz, M. (2011). Malaysian path to sustainable development: transitions to sustainability. Malaysian Journal of Environmental Management, 12(2), 77-89.

Ahmad Sunawari, L. (2015). Metodologi Penyelidikan Pengajian Islam. 2nd edition. Penerbit Universiti Kebangsaan Malaysia, Bangi.

Alias, A. (2013). Sains dan teknologi dalam ketamadunan islam: Analisa epistemologi dan metodologi. Jurnal Al-Tamaddun Bil, 8(1), 51-66.

Bagoes, W. (2015). 'Green building'and sustainable development policy in Indonesia since 2004. International Journal of Sustainable Building Technology and Urban Development(ahead-of-print), 6(2), 82-89.

Burnett, J. (2007). Sustainability and sustainable buildings. HKIE Transactions, 14(3), 1-9.

Farahwahida, M. Y., Arieff Salleh, R., Salwa, M., Siti Hajar, M. S., \& Teh Ubaidah, N. (2013). Green Technology Management in the Muslim World. Jurnal Teknologi, 65(1), 107-115

Green Technology Financing Scheme. (2016). Senarai Projek Yang Memiliki Sijil GTFS. Capaian di www.gtfs.my

Hazura, A. B., \& Sharifah Norhaidah, S. I. (2007). Pemeliharaan alam tabii bersumberkan pengetahuan islam. Pendidikan Sains, 1(7), 31-44.

Jamalinezhad, M., Talakesh, S. M., \& Soltani, S. H. K. (2012). Islamic Principles and Culture Applied to Improve Life Quality in Islamic Cities. Procedia-Social and Behavioral Sciences, 35, 330-334. doi:10.1016/j.sbspro.2012.02.095 
Kamarudin, A. B., Mohd Fazli, M. S., Md Nor Hayati, T., Ismi Rajiani, \& Norhana, M. (2011). Green Technology Compliance in Malaysia for Sustainable Business Development. Journal of Global Management, 2(1), 55-65.

KeTTHA. (2009). Dasar Teknologi Hijau Kebangsaan. Capaian di http://www.greentechmalaysia.my/National\%20Green\%20Technology\%20Policy\%202009.pdf

Mohamad Akram, L. (2013). Financing Green Technologies and The Role of Islamic Finance: Shari'ah Views. Kertas kerja dibentangkan di the Green Financing: Discover Green Technology Industri In Malaysia, Current and Future Prospects of Islamic Financing Solutions Forum.

Mohd Koharuddin, M. B. (2002). Sains dan Teknologi Asia: Hadiah Asia kepada Dunia. Jurnal Teknologi, 37(1), $29-46$.

Nahadi, M., Sarimaya, F., \& Rosdianti, S. R. (2011). Hubungan Islam dengan Ilmu Pengetahuan Alam dalam Perspektif Sejarah. ATIKAN, 1(1), 2011.

Puvanasvaran, A. P., Miza Farhana, Y. Z., Zaid Ahmaed Al-Hayali, \& Mukhiffun, M. (2012, 15-16 Oktober 2012). Sustainability of Green Technology in Malaysia Industry. Kertas kerja dibentangkan di the International Conference on Design and Concurrent Engineering.

Ruzian, M., \& Norizan, H. (2014). Kelestarian alam sekitar dan pembiayaan teknologi hijau dari perspektif undang-undang syariah. Jurnal Kanun, 26(2), 268-287.

Tam, V. W. Y., Hao, J. L., \& Zeng, S. X. (2012). What affects implementation of green buildings? An empirical study in Hong Kong. International Journal of Strategic Property Management, 16(2), 115-125. doi:10.3846/1648715X.2011.645559

Tobias, L., \& Vavaroutsos, G. (2012). Retrofitting Buildings to be Green and Energy-Efficient: Optimizing Building Performance, Tenant Satisfaction, and Financial Return: Urban Land Institute Chicago, IL, USA. 